DOI: $10.32347 / 2076-815 \times .2021 .78 .508-519$

UDC 69.5:630:686

Doctor of Technical Sciences, Professor Chernyshev Denys, chernyshev.do@knuba.edu.ua, ORCID: 0000-0002-1946-9242, graduate student Prykhodko Oleh, prykhodko.oo@knuba.edu.ua, ORCID: 0000-0002-3092-6782 graduate student Zhaldak Ruslan, zhaldak.ry@knuba.edu.ua, ORCID: 0000-0002-6139-1506, Ph.D. Vakolyuk Anatoliy, vakolyuk.as@knuba.edu.ua, ORCID: 0000-0003-0599-6436, graduate student Nikolaev Georhii, nikolaev_gv@knuba.edu.ua ORCID: 0000-0003-4135-1467, graduate student Krychevsky Oleksandr, krychevskyi_om@knuba.edu.ua ORCID: 0000-0001-5917-3000, graduate student Myrutenko Oleksandr, myrutenko_ov@knuba.edu.ua ORCID: 0000-0003-1686-261X, Kyiv National University of Construction and Architecture, Kyiv

\title{
FUNCTIONAL-TECHNOLOGICAL SUBSYSTEMS OF DIGITAL TRANSFORMATIONS OF BUSINESS PROCESSES AND ORGANIZATIONAL STRUCTURES OF CONSTRUCTION ENTERPRISES
}

The article presents methodology of business processes reengineering (BPR) in the modern construction organizations adapted to dynamically changing conditions of the internal and external environment.

The ontological analysis carried out in the article allowed to distinguish the dominant characteristics of business process reengineering (BPR) as a phenomenon and a target project. It was justified to consider reengineering through the following dominants:

- $\quad$ mandatory for reengineering format of a temporary specialized project of local or cardinal transformations;

- the main goal of BPR is to direct the transformation of business processes, operational and production and administrative systems of the enterprise for their joint reconfiguration to ensure a sharp increase in competitiveness of the studied enterprise (among similar enterprises in actually occupied or potential markets ;

- increase in the functional quality of production and administration processes, which will ultimately ensure a significant increase in the quality of the 
operating system of the enterprise and a proper increase in its resilience to crises (destruction, loss of economic balance and financial stability, bankruptcy, etc.).

Formalization of the BPR methodology ensures the combination of reverse and direct reengineering stages. The results of the study allow solving urgent problems of increasing the competitiveness of construction organizations through reengineering design. The scientific significance of the study lies in the development of a component methodology for modeling reengineering of business processes. The practical significance of the use lies in the application of the study in the real sector of the economy during the restructuring and reform of construction organizations. The scientific novelty of the study lies in the development of a methodology and conceptual provisions for systemic management of business process reengineering of building organizations based on the use of the process approach.

Keywords: business processes reengineering; BPR; component methodology; formalization of the business processes structure; restructuring; reorganization.

Statement of the problem. In the construction industry recently there are serious quantitative and qualitative changes, which together with the known achievements cause a number of difficulties in the management and organization of construction production due to the constant reduction in scale and volume of construction, increasing quality requirements, elimination of large organizations. the emergence of various forms of ownership of small developers.

As a result, a situation has arisen where the huge labor and technical potential of the industry is not used effectively enough. Builders often fail to put into operation a number of facilities and facilities, do not fully and irrationally use construction equipment, there are significant losses of working time on construction sites.

In the current context of overcoming the crisis in the construction industry, productive ways to overcome it and further develop it for enterprises in the industry are associated with reengineering.

Business process reengineering is one of the most important tools aimed at updating or rebuilding business processes at construction enterprises to achieve a radical increase in the efficiency of their functioning. The meaning and content of reengineering is a radical rethinking and fundamental redesign of business processes in order to achieve significant (tens or even hundreds of times) growth of key performance indicators of the enterprise.

Analysis of recent studies and publications. In scientific works [1-3], individual elements of the reengineering of managerial business processes are formulated. The theory of reengineering was developed into an independent management concept at the end of XX century in the works of M. Hammer, J. Champ, T. Davenport. The main reason for this served as a decrease in the efficiency 
of business models and management approaches.

The authors M. Hammer and J. Champy [4] define the reengineering of business processes and understand the fundamental rethinking and radical modification of business processes to achieve a turning point in improving critical current indicators, such as costs, quality, service and speed of business processes.

In articles $[5,6]$ it is indicated that the object of reengineering is business processes, and not the structure of enterprises or their individual functions. Based on the analysis of the theory and practice of business process reengineering, it is proposed to consider unproductive operations and relationships between performers as a separate business process as a subject of reengineering.

The authors [7-9] define the reengineering of business processes as a philosophy of improvement, the main task of which is to achieve fundamental improvements by redesigning the process to maximize value and minimize other indicators.

The authors of the papers [10-13] consider the links of reengineering with other management concepts such as restructuring and reorganization. Restructuring refers to the development and implementation of measures to bring the organization in line with the needs of a particular market Business process reengineering aims to create a flexible business model that can easily adapt to the requirements and market shifts of various markets. Restructuring allows you to find a way out of existing problematic situations, and reengineering allows you to use the opportunities, potential of the company. Reorganization involves changing the external structure of the business, while reengineering aims to transform the internal structure.

Formulation of goals. The aim of the work is to improve the methodological approach and formalized analytical basis for finding ways to develop enterprises in the construction industry through the reengineering of their operational and production system (business processes) and organizational management structure.

Relevance and novelty. The main ultimate goal of business process reengineering is flexibility and efficiency of adapting to predicted changes in consumer requests: appropriate adjustment of strategy, technology, organization of production and management, based on which effective automation currently lies.

Business process reengineering (BPR) is the practice of rethinking and redesigning the way work is done to better support an organization's mission and reduce costs. Organizations reengineer two key areas of their businesses. First, they use modern technology to enhance data dissemination and decision-making processes. Then, they alter functional organizations to form functional teams. Reengineering starts with a high-level assessment of the organization's mission, strategic goals, and customer needs. Basic questions are asked, such as "Does our mission need to be redefined? Are our strategic goals aligned with our 
mission? Who are our customers?" An organization may find that it is operating on questionable assumptions, particularly in terms of the wants and needs of its customers. Only after the organization rethinks what it should be doing, does it go on to decide how best to do it.

Proposed methodology. Re-engineering recognizes that an organization's business processes are usually fragmented into sub-processes and tasks that are carried out by several specialized functional areas within the organization. Often, no one is responsible for the overall performance of the entire process. Reengineering maintains that optimizing the performance of sub-processes can result in some benefits but cannot yield improvements if the process itself is fundamentally inefficient and outmoded. For that reason, re-engineering focuses on re-designing the process as a whole in order to achieve the greatest possible benefits to the organization and their customers. This drive for realizing improvements by fundamentally re-thinking how the organization's work should be done distinguishes the re-engineering from process improvement efforts that focus on functional or incremental improvement,

The object of this study is the reengineering of business processes aimed at the effective restructuring of construction enterprises in accordance with their strategic goals and specific operating conditions. Restructuring of enterprises is interpreted not just as organizational restructuring, but a change in the strategy of financial and economic activity, which determines the transformation of the methods of functioning of the enterprise. Restructuring leads to a change in the nature of production activities, the redistribution of financial, material and human resources, attracting additional sources of financing. The effectiveness of the enterprise is determined by the correct strategic positioning in the market, the ability to introduce new activities, rebuild or abandon existing ones, establish partnerships with other enterprises.

It is proposed to use reengineering of business processes that implements a process approach to enterprise management as an effective method of restructuring. The need for business process reengineering is determined by the following factors:

- complex production structure;

- $\quad$ territorial distribution of units; a large number

- $\quad$ cooperative ties; versatility;

- dynamism and client-oriented financial and economic activities of modern enterprises.

Reengineering business processes (RBP) allows concentrating on obtaining the final result of the process, increases the degree of coordination of operations, dramatically accelerates business processes and improves quality work. Concentration of funds on the reengineering of key business processes, in turn, 
dramatically increases the effectiveness of restructuring enterprises.

The figure 1 shows the relation of reengineering business processes in the modern management system.

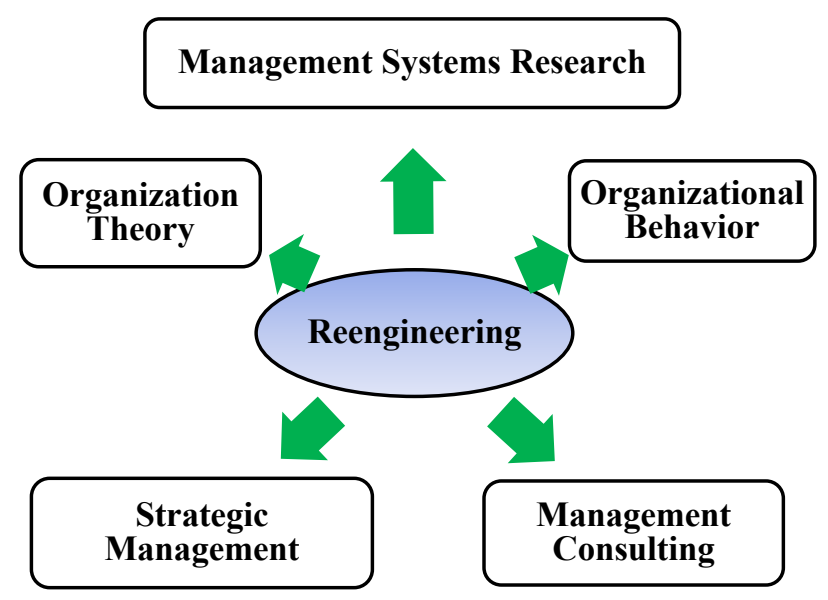

Fig. 1. Relation of business processes reengineering in the modern management system

Significant structural changes to the construction organization during the reengineering of business processes, accompanied by the transition to new principles of work of the organization, require the development and implementation of a special project and the creation of a reengineering team, including both the staff of the organization and invited consultants.

The construction organization proceeds to a new period of development after the intended goals of work on the project of the previous stage are reached. Permanent small upgrades are performed during the ongoing work. it is necessary to re-engineer the organization as the possibilities of gradual improvements, organization, are exhausted. But usually in this case, the project already covers not only the entire construction organization, but only its individual units. Thus, continuous activities to change the organization become part of its daily life in response to the constant changes of various environmental factors: market, technology, customer preferences, competition and so on.

The development of the component methodology of the RBP is an urgent task for the successful restructuring of enterprises.

The proposed methodology, in contrast to existing methodologies, allows automating the selection and configuration of adequate components of the structure of business processes that reflect the experience in the implementation of RBP for various types of enterprises.

It is necessary to formalize the formulation of the task of reengineering business processes on the basis of component configuration of the enterprise's structure. It is advisable to apply a systematic approach to determining the functions 
and patterns of interaction of business processes.

An enterprise is considered as a goal-oriented structure of potential and processes, which is based on the representation of system (S) as a tuple of components:

$$
S=\langle C, F, R\rangle
$$

where $\boldsymbol{C}$ is a set of system components, $\boldsymbol{F}$ is a set of functions (activities, business processes, operations), $\boldsymbol{R}$ is a set of relations.

Formalization of the structure of business processes is an important task of their reengineering. From the composition of system elements defined by relation (1), functions that process, use, and form other elements are identified in a separate category. In this way, some transformations and processes are realized, and regularities are determined according to which the functioning of the system is organized.

The set of system components $\boldsymbol{C}$ is described by such a tuple of sets:

$$
C=\langle X, Y, Z, T, G, M\rangle
$$

where $\boldsymbol{X}$ is a set of input elements, $\boldsymbol{Y}$ is a set of output elements, $\boldsymbol{Z}$ is a set of external environment elements, $\boldsymbol{T}$ is the period of time over which the system, $\boldsymbol{G}$ is a set of goals of functioning system, $\boldsymbol{M}$ is a set of methods (strategies, patterns) of functioning system.

The participation of components in functions is defined by certain role relations. Elements participate in the execution of the function as input and output objects, means, people and their organizations participate in the execution of functions as executors, initiators, recipients of the result. It is necessary to determine the goal of fulfillment or a criterion, a method of execution based on the use of a strategy or a specific method of organizing a process that optimizes the achievement of a goal for the implementation of a function. In addition, it is necessary to determine the time interval for the function.

The participation of system components $\boldsymbol{C}$ in functions $\boldsymbol{F}$ is defined by certain role relations:

$$
\mathrm{R}=\left\{R_{i}\right\}_{i=\overline{1 . N r}}
$$

where $N r$ is the total number of relations in the system, $R_{i}$ is a $i$-role relation with such structure:

$$
R_{i}=r\left(C_{i}, F_{k}\right)
$$

where $C_{i}$ is a $j$-component of the system that participates in the corresponding $i$-role 
$R_{i}$ in the execution of the $k$-function $F_{k}$.

The set of functions $F$ is a converter of the input elements $X$ to the output elements $Y$ :

$$
Y=F(X)
$$

where $F=\left\{F_{k}\right\}_{k=1, \overline{1} \text {, }}, X=\left\{X_{l}\right\}_{l=\overline{1, N x}}, Y=\left\{Y_{h}\right\}_{h=\overline{1, N y}}, N f$ is the total number of functions in the system. $N x$ is the total number of input elements in the system. $N y$ is the total number of output elements in the system.

Thus, the choice of objective functions and limitations, the allocation of functions and elements, the interaction of all these components in the processes should correspond to some regularity of the enterprise's functioning inherent to its potential and environment.

Analytical expressions of objective functions are relatively easy to obtain for single-criteria and difficult to express in the case of multi-criteria dependencies. Factors determining the objective function can have rather complex dependencies. The tasks of the RBP are becoming poorly formalized; their decisions largely determine the strategy or method of organizing business processes.

In this case, to obtain integral estimates of achieving the goals of the system, qualitative heuristic models are used that operate on incomplete, fuzzy and even contradictory information.

It is proposed to use the methods of the theory of artificial intelligence as methods for constructing such models, which make it possible to determine the class of an enterprise that corresponds to some typical patterns of behavior (functioning) that determine the choice of the necessary components of the types of activities and the business processes that form them.

At the same time, it is proposed to extract knowledge about components and their relationships from a knowledge management system based on formalized rules.

Result and discussion. Studies on the reengineering of business processes at Ukrainian enterprises in the construction industry have shown the high efficiency of the measures taken, despite the fact that the process turned out to be quite laborintensive and took two years to complete.

The figure 2 shows the sequence of stages for applying methodology business process reengineering in the construction management system.

At the first stage (preparatory), a reengineering process management system was developed. Specific employees were selected, appointed and approved participants in the BPO, their functions and responsibilities were determined, employees were motivated to innovate, a scheme for their interaction was developed, etc. 


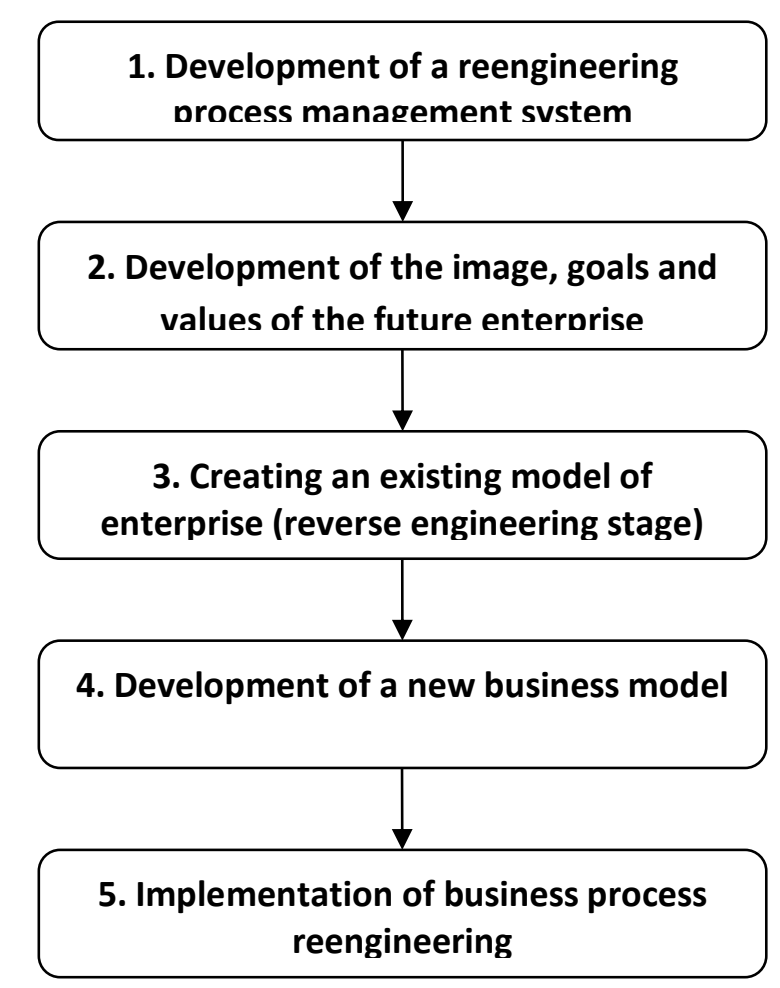

Fig.2. Stages of applying methodology of business process reengineering in the construction management system

At the second stage, specialists formed the image of the future enterprise, determined its goals and values. The problems that the enterprise has have been identified and clearly formulated. The choice of business processes for reengineering was determined, which are the most significant for the enterprise and its customers, that is, both strategic and creating value. For the implementation of business process reengineering, the allocation of the required additional material, human, financial and time resources was organized. Working groups were created that began to work on the development of the RBP project.

Conclusion. The concept of a methodology for reengineering business processes is theoretically substantiated based on the adequate construction of a conceptual system model from the components displayed in the modern enterprise management system. This methodology provides increased efficiency financial and economic activities in accordance with strategic objectives, potential and operating conditions of construction development.

The formalization of the business process reengineering task at all stages on the basis of a systematic approach and component technology is described. This approach allows to effectively managing resources during the BPR.

Formalization of the BPR methodology ensures the combination of reverse and direct reengineering stages. As a result of the parametric description of the subject area, variants of the structural organization of business processes are formed, which 
are supposed to be analyzed using the tools of heuristic, mathematical and simulation modeling.

д.т.н., професор Чернишев Д. О.,

Приходько О.О., Жалдак Р.Ю., к.т.н. Ваколюк А.С., Ніколаєв Г.В., Кричевський О.М., Мірутенко О.В., Київський національний університет будівництва і архітектури

\section{ФУНКЦІОНАЛЬНО-ТЕХНОЛОГІЧНІ ПІДСИСТЕМИ ЦИФРОВИХ ТРАНСФОРМАЦЙ БІЗНЕС-ПРОЦЕСІВ ТА ОРГСТРУКТУР БУДІВЕЛЬНИХ ПІДПРИЄМСТВ}

У статті представлено методологію реінжинірингу бізнес-процесів (BPR) в сучасних будівельних організаціях, адаптованих до динамічно мінливих умов внутрішнього та зовнішнього середовища. Проведений онтологічний аналіз дозволив вирізнити домінантні характеристики реінжинірингу бізнес-процесів (Business Process Reengineering - BPR) як явища та цільового проєкту. Було обгрунтовано розглядати реінжиніринг через наступні домінанти:

$>$ обов'язковий для реінжинірингу формат тимчасового спеціалізованого проєкту локальних чи кардинальних трансформацій;

$>$ провідною метою $B P R \in$ спрямування трансформацій бізнес-процесів, операційно-виробничої та адміністративно-управлінських систем підприємства - для їх сумісного переналаштування на забезпечення стрибкоподібного зростання конкурентоздатності досліджуваного підприємства (серед підприємств-аналогів на фактично зайнятих чи потенційних ринках виробництва і споживання кінцевого продукту підприємства);

зростання функціональної якості виконання процесів виробництва та адміністрування, що в підсумку забезпечить як суттєве зростання якості функціонування операційної системи підприємства, так і належне зростання його стійкості щодо кризових явищ (деструкції, втрати економічної рівноваги та фінансової стійкості, банкрутства тощо).

Формалізація методології BPR забезпечує поєднання етапів зворотного та прямого реінжинірингу. Результати дослідження дозволяють вирішувати актуальні проблеми підвищення конкурентоспроможності будівельних організацій шляхом реінжинірингового проектування. Наукова значимість дослідження полягає у розробці компонентної методології моделювання реінжинірингу бізнес-процесів. Практичне значення використання полягає у застосуванні дослідження в реальному секторі економіки під час реструктуризації та реформування будівельних організацій. Наукова новизна 
дослідження полягає у розробці методології та концептуальних положень системного управління реінжинірингом бізнес-процесів будівельних організацій на основі використання процесного підходу.

Ключові слова: реінжиніринг бізнес-процесів; BPR; компонентна методологія;формалізація структури бізнес-процесів; реструктуризація; реорганізація.

д.т.н., профессор Чернышев Д.О., Приходько О.А., Жалдак Р.Ю., к.т.н. Ваколюк А.С., Николаев Г.В., Кричевский А.М.,Мирутенко А.В., Киевский национальный университет строительства и архитектуры

\section{ФУНКЦИОНАЛЬНО-ТЕХНОЛОГИЧЕСКИЕ ПОДСИСТЕМЫ ЦИФРОВЫХ ТРАНСФОРМАЦИЙ БИЗНЕС-ПРОЦЕССОВ И ОРГСТРУКТУР СТРОИТЕЛЬНЫХ ПРЕДПРИЯТИЙ}

В статье представлена методология реинжиниринга бизнес-процессов (BPR) в современных строительных организациях, адаптированных к динамически меняющимся условиям внутренней и внешней среды. Проведенный онтологический анализ позволил выделить доминантные характеристики реинжиниринга бизнес-процессов (Business Process Reengineering - BPR) как явления и целевого проекта. Дано обоснование о необходимости рассматривать реинжиниринг через следующие доминанты:

$>$ обязательный для реинжиниринга формат временного специализированного проекта локальных или кардинальных трансформаций;

$>$ ведущей целью BPR является направление трансформаций бизнеспроцессов, операционно-производственной и административно-управленческих систем предприятия - для их совместного перенастройки на обеспечение скачкообразного роста конкурентоспособности исследуемого предприятия (среди предприятий-аналогов на фактически занятых или потенциальных рынках производства и потребления конечного продукта предприятия);

$>$ рост функционального качества выполнения процессов производства и администрирования, что в итоге обеспечит как существенный рост качества функционирования операционной системы предприятия, так и надлежащий рост его устойчивости по отношению к кризисным явлениям (деструкции, потере экономического равновесия и финансовой устойчивости, банкротству и т.п.).

Формализация методологии BPR обеспечивает соединение этапов обратного и прямого реинжиниринга. Результаты исследования позволяют 
решать актуальные проблемы повышения конкурентоспособности строительных организаций путём реинжинирингового проектирования. Научная значимость исследования состоит в разработке компонентной методологии моделирования реинжиниринга бизнес-процессов. Практическое значение использования заключается в применении исследования в реальном секторе экономики при реструктуризации и реформировании строительных организаций. Научная новизна исследования состоит в разработке методологии и концептуальных положений системного управления реинжинирингом бизнеспроцессов строительных организаций на основе использования процессного подхода.

Ключевые слова: реинжиниринг бизнес-процессов; BPR; компонентная методология; формализация структуры бизнес-процессов; реструктуризация; реорганизация.

\section{REFERENCES}

1. M. Bertolini, M. Bevilacqua, F.E. Ciarapica, G. Giacchetta, Business process reengineering in healthcare management: a case study, Business Process Management Journal, Vol. 17, Iss. 1, 2011. \{in English\}

2. Sh. Dezdar, S. Ainin, Examining ERP implementation success from a project environment perspective, Business Process Management Journal, Vol. 17. Iss. 6, 2011. \{in English $\}$

3. J. Choudrie, V. Hlupic, Z. Irani, Teams and their Motivation for Business Process Reengineering: A Research Note, International Journal of Flexible Manufacturing Systems, Vol. 14. Iss. 1, 2002. \{in English\}

4. M. Hammer, J. Champy, Reinzhiniring korporatsii: Manifest revoliutsii $v$ biznese [Reengineering the corporation: A Manifesto for business revolution]. Saint-Petersburg, Izdatel'stvo Sankt-Peterburgskogo universiteta, 2000. 332 p. \{in Russian\}

5. Chernyshev, D., Ryzhakov, D., Dikiy, O., Khomenko, O., Petrukha, S. Innovative technology for management tools of commercial real estate in construction International Journal of Emerging Trends in Engineering Researchthis link is disabled, 2020, 8(9), стр. 4967-4973. \{in English\}

6. Marchuk Tetyana Identification of the basic elements of the innovationanalytical platform for energy efficiency in project 20.-financing. Investment Management and Financial Innovations. 2017. - Vol. 14(4), pp. 12 DOI:http://10.21511/imfi.14(4).2017.02. \{in English\}

7. G. Ryzhakova, K. Chupryna, I. Ivakhnenko Expert-analytical model of management quality assessment at a construction enterprise /. Scientific Journal of Astana IT University, Volume 3, September 2020. P. 71-82 \{in English\} 
8. Ryzhakova, Galyna, Ivakhnenko, Iryna, Chupryna, Iurii (2021). Information-analytical support and organizational-structural regulation of operational activity of enterprises: economic evaluation and construction of management systems. Management of development of complex systems, 46, 91-99; dx.doi.org \10.32347/2412-9933.2021.46.91-99. \{in Ukrainian\}

9. Ryzhakova, Galyna, Petrukha, Serhiy. The innovative technology for modeling management business process of the enterprise. International Journal of Recent Technology and Engineering (IJRTE). No. 8 (4), pp. 4024 - 4033. DOI:10.35940/ijrte.D8356.118419 \{in English\}

10. Honcharenko, T., Ryzhakova, G., Borodavka, Y., Savenko, V., Polosenko, O. Method for representing spatial information of topological relations based on a multidimensional data model ARPN Journal of Engineering and Applied Sciences, 2021, 16(7), pp. 802-809. \{in English\}

11. Tormosov, R., Chupryna, I., Ryzhakova, G., Prykhodko, D., Faizullin, A. Establishment of the rational economic and analytical basis for projects in different sectors for their integration into the targeted diversified program for sustainable energy development SIST 2021 - 2021 IEEE International Conference on Smart Information Systems and Technologies, 2021, 9465993. \{in English\}

12. Revunov, Oleksandr, Ryzhakova, Galyna, Malykhina, Oksana (2021). Analytical tools for diagnostics of quality management systems of enterprisesstakeholders of construction projects. Management of Development of Complex Systems, 45, 161-169, dx.doi.org \10.32347/2412- 9933.2021.45.161-169. \{in Ukrainian\}

13. Kulikov P., Ryzhakova G., Honcharenko T., Ryzhakov D. \& Malykhina O. 2020. OLAP-Tools for the Formation of Connected and Diversified Production and Project Management Systems. International Journal of Advanced Trends in Computer Science and Engineering. 9(5): 8670-8676. \{in English\} 